\title{
Effects of rearing density on sea bass (Dicentrarchus labrax) biological performance, blood parameters and disease resistance in a flow through system
}

\author{
Emmanuelle Roque d'Orbcastel ${ }^{1}$, Gilles Lemarié ${ }^{1}$, Gilles Breuil ${ }^{1}$, Tommaso Petochi ${ }^{2}$, \\ Giovanna Marino $^{2}$, Sébastien Triplet ${ }^{1}$, Gilbert Dutto ${ }^{1}$, Sveinung Fivelstad ${ }^{3}$, Jean- Luc Coeurdacier ${ }^{1}$ \\ and Jean-Paul Blancheton ${ }^{1, a}$ \\ 1 Ifremer, Chemin de Maguelone, 34250 Palavas-les-Flots, France \\ 2 ISPRA, Aquaculture Unit, Via Casalotti 300, Rome 00166, Italy \\ 3 Bergen University College, Nygårdsgaten 114, 5020 Bergen, Norway
}

Received 6 May 2009; Accepted 10 November 2009

\begin{abstract}
During 84 days, the effects of density on juvenile sea bass (Dicentrarchus labrax) (76 $\pm 16 \mathrm{~g})$ were studied in an experimental tank-based flow through system. Performance, stress response and resistance to virus infection were analysed under five stabilized rearing densities: 10, 20, 40, 70 and $100 \mathrm{~kg} \mathrm{~m}^{-3}$. Water quality parameters $\left(\mathrm{CO}_{2}\right.$, total ammonia nitrogen and $\mathrm{O}_{2}$ ) were measured and maintained close to the recommended values for farmed sea bass by adjusting water renewal exchange. No significant differences were observed between density treatments, neither on stress response (cortisol) nor susceptibility to nodavirus. With regards to biological performances, the daily feed intake and specific growth rate were significantly lower in fish reared at the $100 \mathrm{~kg} \mathrm{~m}^{-3}$ density. Results on the effects of density in sea bass reared in flow through (present study) and in recirculating aquaculture systems (RAS) (Sammouth et al. 2009) were compared as a contribution to the identification of density not affecting health and welfare in farmed sea bass.
\end{abstract}

Key words: Rearing density / Flow through system / Stress / Water quality / Sea bass

\begin{abstract}
Résumé - Les effets de la densité en élevage sur les performances et le bien-être de bars (Dicentrarchus labrax) (76 $\pm 16 \mathrm{~g})$ sont étudiés dans un système expérimental en circuit ouvert durant 84 jours. Les performances biologiques, la réponse au stress et la résistance à une infection virale sont étudiées sur des lots de poissons élevés à 5 densités différentes d'élevage stabilisées : 10, 20, 40, 70 et $100 \mathrm{~kg} \mathrm{~m}^{-3}$. La qualité de l'eau est maintenue équivalente dans tous les bassins et au long de 1'expérimentation en ajustant les taux de renouvellement en eau neuve. En particulier, les concentrations en $\mathrm{O}_{2}, \mathrm{CO}_{2}$, et azote ammoniacal total sont stabilisées autour des niveaux recommandés pour le bar d'élevage. Aucune différence significative n'est observée entre les différents traitements, sur la réponse au stress (cortisol) et sur la sensibilité au nodavirus (tests infectieux). La prise alimentaire quotidienne et le taux de croissance spécifique sont significativement inférieurs dans les lots maintenus à $100 \mathrm{~kg} \mathrm{~m}^{-3}$. Ces résultats sont comparés à ceux obtenus au cours d'expériences similaires en circuit fermé (Sammouth et al. 2009). Il ressort que, dans la gamme testée, la densité n'apparaît pas comme un facteur limitant pour la santé (résistance à des infections virales) et bien-être (niveau de cortisol) du bar, pourvu que des conditions de bonne qualité de l'eau soient maintenues.
\end{abstract}

\section{Introduction}

Increased fish density in aquaculture units is a management tool for reducing running costs per $\mathrm{kg}$ of fish produced and thus ensuring the economic sustainability (viability) of the production cycle. Large ranges of densities are commonly used for farmed sea bass, from less than 10 to more than $100 \mathrm{~kg} \mathrm{~m}^{-3}$,

\footnotetext{
a Corresponding author: jean.paul.blancheton@ifremer. fr
}

according to the type of rearing system and size (Ellis et al. 2002). Parallel to this, fish welfare considerations are today important for ensuring the social acceptability of the marketed product (Conte 2004; Ashley 2007). Broadly speaking, density is considered to be responsible for negative effects on fish performance and welfare (Ellis et al. 2002). Nevertheless, a few studies (Turnbull et al. 2005; Roncarati et al. 2006; Di Marco et al. 2008) report on density effects on European 
Table 1. Recommended water quality levels for sea bass aquaculture (Blancheton 2000).

\begin{tabular}{lccc}
\hline & Larvae & Fingerlings & Adults \\
\hline Temperature $\left({ }^{\circ} \mathrm{C}\right)$ & $16-20$ & $22-24$ & $22-24$ \\
$\mathrm{pH}$ & $7.5-8.3$ & $6.5-8.3$ & $6.5-8.3$ \\
$\mathrm{O}_{2}(\%$ saturation$)$ & $>90$ & $>90$ & $>90$ \\
$\mathrm{CO}_{2}(\mathrm{mg} \mathrm{L}$ & \\
Total ammonia nitrogen, $\mathrm{TAN}\left(\mathrm{mg} \mathrm{L}^{-1}\right)$ & - & $<40$ & $<40$ \\
Nitrite nitrogen, $\mathrm{NO}_{2}-\mathrm{N}\left(\mathrm{mg} \mathrm{L}^{-1}\right)$ & $<0.2$ & $<0.5$ & $<2$ \\
Nitrate nitrogen, $\mathrm{NO}_{3}-\mathrm{N}\left(\mathrm{mg} \mathrm{L}^{-1}\right)$ & $<0.2$ & $<0.5$ & $<2$ \\
\hline
\end{tabular}

sea bass (Dicentrarchus labrax) welfare in farms. Ellis et al. (2002) reviewed more than 40 studies concerning density effects on fish health in rainbow trout, most of them associated fish performance degradation at high density due to fish stress, aggressive interactions and the development of feeding hierarchies (Wallace et al. 1988; Baker and Aylers 1990; Pickering 1992; Alanärä and Brännäs 1996). Conversely, other studies reported that very low densities could impact feed intake because of the establishment of hierarchical feeding behaviour (Papoutsoglou et al. 1987, 1990; Pickering et al. 1989; Zoccarato et al. 1994). Most studies on the density effects on fish welfare do not generally distinguish between specific effects related to biomass increase per se and those caused by the degradation of water quality (Person-Le-Ruyet et al. 2008). However, water quality deterioration can impact the nutritional status, causing physiological stress and susceptibility to diseases (Meade 1989; Noble and Summerfelt 1996). Björnsson and Ólafsdóttir (2006) studied the effects of water quality and stocking density on the growth performance of juvenile cod (Gadus morhua L.) in a flow through system and in a recirculating system. They observed a negative correlation between relative growth rate and total ammonia nitrogen (TAN), suggesting TAN concentrations of around $1.3-1.5 \mathrm{mg} \mathrm{L}^{-1}$ may have been a limiting factor in the recirculating system.

It seems that high densities $\left(>110 \mathrm{~kg} \mathrm{~m}^{-3}\right)$ can be reached in aquaculture systems without impacting fish performance and welfare (Wallace et al. 1988; Jorgensen et al. 1993; Roque d'orbcastel et al. 2009), especially in well oxygenated or aerated systems (Baker and Ayles 1990; North et al. 2006) and when water quality is kept close to the recommended levels. Several authors have described water quality requirements for Mediterranean farmed fish (Blancheton 2000; Pichavant et al. 2001; Person-Le-Ruyet et al. 2002, 2004; Dosdat 2003; Lemarié et al. 2004). Safe water quality levels for sea bass rearing are given at around $0.5-2 \mathrm{mg} \mathrm{N} \mathrm{L}^{-1}$ for total ammonia nitrogen (TAN) and nitrite-nitrogen $\left(\mathrm{NO}_{2}-\mathrm{N}\right), 6-7 \mathrm{mg} \mathrm{O}_{2} \mathrm{~L}^{-1}$ and below $40 \mathrm{mg} \mathrm{CO}_{2} \mathrm{~L}^{-1}$.

This paper analyzes the effect of density on the welfare of sea bass reared in a flow through system (FTS). Fish performance, stress response and resistance to virus infection were monitored at five stabilized densities: 10 20, 40, 70 and $100 \mathrm{~kg} \mathrm{~m}^{-3}$ for 84 days. In order to distinguish between the effects of water quality deterioration and those due to biomass per se, water quality parameters were kept under control and maintained at recommended safe levels for sea bass throughout the experiment.

\section{Materials and methods}

\subsection{Facility and water quality}

The experimental facility was composed of 10 circular tanks $\left(1 \mathrm{~m}^{3}\right.$ each) operated in a flow through system. Each tank was covered with a black plastic sheet to protect the fish from external visual stress. A particle trap $(50 \mathrm{~L})$ was fitted outside each tank and crossed by part of the outlet flow to remove solid waste (faeces and uneaten feed). Light intensity was 500 lux using an incandescent lamp (OSRAM Decor Silver E27) and the photoperiod was maintained at $16 \mathrm{~h}$ light $-8 \mathrm{~h}$ dark, including $30 \mathrm{~min}$ of artificial dawn and dusk.

Before use, inlet water was sand filtered, UV treated and $21{ }^{\circ} \mathrm{C}$ heated with a titanium exchanger. The temperature was monitored daily with a mercury thermometer $\left( \pm 0.1{ }^{\circ} \mathrm{C}\right)$ and salinity with an ATAGO hand refractometer $( \pm 2 \%$ ).

The water was super-oxygenated at 25 and $14 \mathrm{mg} \mathrm{L}^{-1}$ levels, respectively using a bicone system (pressurized $\mathrm{O}_{2}$ injection) and air bubbling in the header tank. According to the $\mathrm{O}_{2}$ concentrations, water flow rates were adjusted from 0.5 to $2.5 \mathrm{~m}^{3} \mathrm{~h}^{-1}$ in order to maintain tank outlet at around 95-110\% saturation. Dissolved oxygen was measured daily in tanks using a WTW oxymeter. The minimal water flow rate was fixed to $0.5 \mathrm{~m}^{3} \mathrm{~h}^{-1}$ to ensure tank self-cleaning and remove waste to the particle trap. Water flow rates were controlled daily with calibrated flow-meters.

The other water quality parameters were controlled weekly to ensure no limiting levels (Table 1) whatever the experimental density. $\mathrm{CO}_{2}$ concentration was measured every 10 days in the tank outlet using a $\mathrm{Li}$-cor $\mathrm{CO}_{2}$ analyser. Water samples were collected in the tank outlet every 10 days for all density groups. Total ammonia nitrogen (TAN), nitrite-nitrogen $\left(\mathrm{NO}_{2}-\mathrm{N}\right)$ and nitrate-nitrogen $\left(\mathrm{NO}_{3}-\mathrm{N}\right)$ concentrations were measured on filtered samples by spectrophotometry according to the method described by Benschneider and Robinson (1952), Solorzano (1969) and Wood et al. (1967). The pH was measured daily in tanks using an Ecoscan ${ }^{\circledR} \mathrm{pH}$ meter.

\subsection{The 84 day - density experiment}

\section{Fish and feed}

Sea bass $\left(76 \pm 16 \mathrm{~g}\right.$ mean weight, $n_{\text {initial }}=6232, n_{\text {final }}=$ 2421) were randomly distributed among the 10 tanks at five 
stabilized rearing densities: $10,20,40,70$ and $100 \mathrm{~kg} \mathrm{~m}^{-3}$, in duplicate. The trial lasted 84 days, and experimental period was divided into 4 successive 21-day periods (P1, P2, P3, P4) to adjust each tank biomass at a constant frequency. At the end of each period, densities were adjusted by random biomass removal.

The fish were fed ad libitum once a day with commercial (biomar ${ }^{\circledR}$ ) expanded pellets ( $43 \%$ protein, $20 \%$ crude fat, $17 \%$ carbohydrate NFE, 7\% ash) from the same production batch. Distribution was made using semi-manual feeders. The feeders $\left(1 / \operatorname{tank}\right.$ for the 10,20 and $40 \mathrm{~kg} \mathrm{~m}^{-3}$ groups, $2 /$ tank for the 70 and $100 \mathrm{~kg} \mathrm{~m}^{-3}$ groups) were poured the day before to avoid any stress before feeding. A switch, located outside each tank, was actuated by the operator who observed the fish behavior through a window in the plastic sheet. At each actuation, the feeder released a predetermined amount of feed (1.7-1.9 g) onto the surface of the water. The switches were activated successively several times until apparent satiety determined by 3 factors: i) fish indifference towards feed, ii) uneaten pellets observed on the tank bottom and iii) first pellets in the particle trap.

\section{Biological performances}

Mortality was controlled daily and dead fish were removed, counted and weighed. The cumulative mortality rate (in $\%$ of the initial fish number) was calculated for each density group.

$$
\text { Cumulative } \operatorname{MR}(\%)=(1(S 1 \cdot S 2 \cdot S 3 \cdot S 4)) \cdot 100
$$

where $\mathrm{S} 1, \mathrm{~S} 2, \mathrm{~S} 3, \mathrm{~S} 4$ = survival of periods $1,2,3,4$ calculated as follows:

$$
S=\frac{100-\left(100 \cdot \frac{n_{f}-n_{i}}{n_{i}}\right)}{100}
$$

where $n_{i, f}$ are the initial and final numbers of fish per period.

At the end of each 21 day period, the total fish biomass of each tank was weighed and any fish in excess were removed to adjust densities. Fish were fasted $24 \mathrm{~h}$ prior to the sampling day and before biometrics fish were anaesthetized in their tank (2-phenoxyethanol, $220 \mathrm{ppm} \mathrm{m}^{-3}$ ). Forty fish per tank were randomly sampled for individual biometrics (length at fork and weight, with $0.1 \mathrm{~cm}$ and $0.1 \mathrm{~g}$ of precision respectively).

Uneaten feed was counted daily in the particle traps and deducted from the distributed feed to evaluate the daily feed intake (DFI, \% $\mathrm{d}^{-1}$ ) as detailed in Equation (3):

$$
D F I=\frac{F / n}{\left(B_{f}+B_{i}\right) / 2} \cdot 100
$$

where $F=$ feed consumption per period $(\mathrm{g}), n=$ number of days of the period and $B_{i, f}=$ the initial and final biomasses (g).

The specific growth rate $\left(\mathrm{SGR}, \% \mathrm{~d}^{-1}\right.$ ) was calculated as follows:

$$
S G R=\frac{(\operatorname{Ln} W f-\operatorname{Ln} W i) \cdot 100}{n}
$$

where $W_{i, f}=$ initial and final body weights $(\mathrm{g})$ of a period, $n=$ number of days of the period.

The feed conversion ratio (FCR) was calculated as the total feed consumption per period divided by the biomass gain on the same period.

\section{Blood parameters}

Cortisol blood concentration was measured at the beginning and the end of the 84 day experiment on fish (total of 48 fish) held at two extreme densities $\left(10\right.$ and $\left.100 \mathrm{~kg} \mathrm{~m}^{-3}\right)$ and an intermediate density $\left(40 \mathrm{~kg} \mathrm{~m}^{-3}\right)$, according to Sammouth et al. (2009). Other blood parameters were measured on fish (total of $40 \mathrm{fish}$ ) with the i-STAT system at the end of the 84 day experiment: sodium $\left(\mathrm{Na}^{+}\right)$, potassium $\left(\mathrm{K}^{+}\right)$, $\mathrm{pH}$, glucose, partial pressure of $\mathrm{CO}_{2}\left(\mathrm{pCO}_{2}\right), \mathrm{HCO}_{3}^{-}$and haematocrit (Hct).

Proteinemia was measured (total of 30 fish) at the beginning, the middle (d31) and the end of experiment on fish from four density groups $\left(10,40,70\right.$ and $\left.100 \mathrm{~kg} \mathrm{~m}^{-3}\right)$ and determined with a Maxmat Hycel auto analyser, based on principle of the biuret reaction. Bovine serum albumin was used as standard and data expressed in $\mathrm{mg} \mathrm{ml}^{-1}$.

\subsection{The 21 day - Nodavirus challenge}

A nodavirus challenge was performed during 21 days on fish from all density groups (i.e. $10,40,70$ and $100 \mathrm{~kg} \mathrm{~m}^{-3}$ ). Fish were checked for nodavirus antibodies according to Breuil and Romestand (1999) and no positive fish were detected (data not shown). At day 84 , thirty fish $(173 \pm 37 \mathrm{~g})$ were individually intramuscularly inoculated according to Varsamos et al. (2006) with slight modifications. Fish were inoculated with a nodavirus suspension $\left(8 \times 10^{5} \mathrm{PFU}\right.$ per fish) for inoculated groups and with sterile saline $\mathrm{NaCl}$ solution for the control group. Fish from each density group were stored at $30 \mathrm{~kg} \mathrm{~m}^{-3}$ in circular tanks $\left(1 \mathrm{~m}^{3}\right.$ each, in triplicate). Inoculated tanks received recirculating water at $25^{\circ} \mathrm{C}$ and the control tank received water at $25^{\circ} \mathrm{C}$ from a separate recirculating system to avoid virus contamination. Total morbidity (i.e. mortality and fish showing abnormal swimming behaviour) was recorded daily for 3 weeks. At the end of the nodavirus challenge, the brains of 10 fish exhibiting nodavirus symptoms (i.e. whirling swimming) were sampled and tested with ELISA for nodavirus antigen detection (Breuil et al. 2001, 2002).

\subsection{Data analysis}

The effect of density on fish performance (DFI, SGR, FCR), water quality and blood parameters was assessed using ANOVA (GLM procedure, SAS Inst., Inc., Cary, NC). The density effect on DFI, FCR and SGR was analysed by a Student Newman-Keuls post-hoc ANOVA, using the tank $(n=2)$ as the experimental unit and the following model:

$$
-Y_{i j}=\mu+\text { density }_{\mathrm{i}}+e_{i j}
$$

where $Y_{i j}$ is the tank performance, $\mu$ is the estimated mean of the population, density $y_{i}$ is the fixed density effect and $e_{i j}$ the residual.

Density effect on blood parameters was performed using individual fish (3-8 per tank) as the experimental unit $(n=41)$ and the following model:

$$
-Y_{i j k}=\mu+\text { density }_{\mathrm{i}}+\operatorname{tank}(\text { density })_{\mathrm{j}}+e_{i j k}
$$


Table 2. Water quality characteristics of the five density groups; different letters following the means \pm SD in the same line indicate significant differences $(p<0.05)$ between the density groups.

\begin{tabular}{lccccc}
\hline & \multicolumn{3}{c}{ Density groups $\left(\mathrm{kg} \mathrm{m}^{-3}\right)$} \\
\cline { 2 - 6 } & 10 & 20 & 40 & 70 & 100 \\
\hline $\mathrm{pH}$ & $7.8 \pm 0.1$ & $7.7 \pm 0.1$ & $7.4 \pm 0.1$ & $7.4 \pm 0.1$ & $7.5 \pm 0.3$ \\
$\mathrm{O}_{2}(\%)$ & $116.9 \pm 18.3 \mathrm{a}$ & $106.6 \pm 19.5 \mathrm{a}$ & $113.6 \pm 18.4 \mathrm{a}$ & $95.0 \pm 17.5 \mathrm{~b}$ & $107.4 \pm 20.7 \mathrm{a}$ \\
$\mathrm{CO}_{2}\left(\mathrm{mg} \mathrm{L}^{-1}\right)$ & $2.0 \pm 0.3$ & $2.8 \pm 0.7$ & $5.0 \pm 1.1$ & $5.5 \pm 1.3$ & $5.4 \pm 1.8$ \\
$\left.\mathrm{TAN}^{-1} \mathrm{~m} \mathrm{~L}^{-1}\right)$ & $0.25 \pm 0.04$ & $0.32 \pm 0.09$ & $0.50 \pm 0.19$ & $0.59 \pm 0.24$ & $0.58 \pm 0.25$ \\
$\mathrm{NO}_{2}-\mathrm{N}\left(\mathrm{mg} \mathrm{L}^{1}\right)$ & $0.01 \pm 0.01$ & $0.01 \pm 0.01$ & $0.01 \pm 0.01$ & $0.01 \pm 0.01$ & 0 \\
$\mathrm{NO}_{3}-\mathrm{N}\left(\mathrm{mg} \mathrm{L}^{1}\right)$ & $0.14 \pm 0.14$ & $0.12 \pm 0.07$ & $0.11 \pm 0.07$ & $0.11 \pm 0.07$ & $0.12 \pm 0.07$ \\
\hline
\end{tabular}

Table 3. Biological performances of the five density groups; different letters following the means \pm SD in the same line indicate significant differences $(p<0.05)$ between the density groups.

\begin{tabular}{lccccc}
\hline & \multicolumn{5}{c}{ Density groups $\left(\mathrm{kg} \mathrm{m}^{-3}\right)$} \\
\cline { 2 - 6 } & 10 & 20 & 40 & 70 & 100 \\
\hline MR $(\%)$ & $1.5 \pm 0.7$ & $0.4 \pm 0.6$ & $2.2 \pm 2.8$ & $1.4 \pm 0.8$ & $12.6 \pm 11.5$ \\
DFI $\left(\% \mathrm{~d}^{-1}\right)$ & $1.44 \pm 0.18 \mathrm{~b}$ & $1.49 \pm 0.22 \mathrm{a}$ & $1.43 \pm 0.14 \mathrm{~b}$ & $1.41 \pm 0.18 \mathrm{~b}$ & $1.31 \pm 0.11 \mathrm{c}$ \\
SGR $\left(\% \mathrm{~d}^{-1}\right)$ & $0.48 \pm 0.05 \mathrm{ab}$ & $0.50 \pm 0.14 \mathrm{a}$ & $0.50 \pm 0.07 \mathrm{a}$ & $0.47 \pm 0.08 \mathrm{ab}$ & $0.43 \pm 0.13 \mathrm{~b}$ \\
FCR & $1.65 \pm 0.11 \mathrm{a}$ & $1.57 \pm 0.08 \mathrm{a}$ & $1.54 \pm 0.08 \mathrm{a}$ & $1.47 \pm 0.16 \mathrm{a}$ & $1.55 \pm 0.25 \mathrm{a}$ \\
\hline
\end{tabular}

Where $Y_{i j k}$ is an individual fish, $\mu$ is the estimated mean of the population, density is $_{i}$ is the fixensity effect, $\operatorname{tank}(\text { density })_{j}$ is the random tank effect relative to density and $e_{i j k}$ the residual.

Cortisol data were analysed by a two-way ANOVA analysis in order to determine the effects of density and time. Posthoc multiple comparisons were performed to evaluate differences between and within groups at sampling times.

The difference in disease resistance was tested with a Kaplan Meier test (Medcalc software).

The level of significance was at $p<0.05$ for all the statistical analyses.

\section{Results}

\subsection{Water quality}

Concentrations of water quality parameters were almost constant in all the experimental tanks and in the range of recommended levels for farmed sea bass (Table 2).

The specific flow rates were 53, 40, 27, 24 and $26 \mathrm{~L} \mathrm{~h}^{-1} \mathrm{~kg}^{-1}$ fish biomass in the 5 stabilized rearing densities, respectively. Water temperature was optimal and constant, $21.2 \pm 0.6{ }^{\circ} \mathrm{C}$. Water salinity was $36.7 \pm 1.6 \%$ and $\mathrm{pH}$ was $7.5 \pm 0.2$.

There was no significant difference $(p>0.05)$ among the values of a same water parameter in the different density groups, except for the $\mathrm{O}_{2}$ saturation which was significantly lower for the $70 \mathrm{~kg} \mathrm{~m}^{-3}$ group $(p<0.05)$ but above $95 \%$ saturation.
In all tanks, nutrient concentrations, expressed as TAN, $\mathrm{NO}_{2}-\mathrm{N}$ and $\mathrm{NO}_{3}-\mathrm{N}$ were below $0.6 \mathrm{mg} \mathrm{L}^{-1}, 0.01 \mathrm{mg} \mathrm{L}^{-1}$ and $0.1 \mathrm{mg} \mathrm{L}^{-1}$ respectively. $\mathrm{CO}_{2}$ concentrations were always below $6 \mathrm{mg} \mathrm{L}^{-1}$.

\subsection{Fish performance and welfare - 84 day experiment}

\section{Biological performances}

Up to $70 \mathrm{~kg} \mathrm{~m}^{-3}$, cumulative mortality rates (Table 3, Fig. 1) were lower than $2.2 \%$ and did not seem to be affected by density. The cumulative mortality rate was higher at $100 \mathrm{~kg} \mathrm{~m}^{-3}(12.6 \pm 11.5 \%$, mean $\pm \mathrm{SD})$ due to a pathology event occurring on one tank during the second period. Without this event, the cumulative mortality rate at $100 \mathrm{~kg} \mathrm{~m}^{-3}$ would have been in the same order of magnitude as the other treatments (around 1.5-2\%).

Average DFI (Table 3, Fig. 1) were in the same order of magnitude $\left(1.3-1.5 \% \mathrm{~d}^{-1}\right)$ for all treatments, with a slight decrease over time which was expected because of the increase in the average weight of fish. Significant differences $(p=0.0008)$ were observed between three groups of treatments: the average DFI of the $20 \mathrm{~kg} \mathrm{~m}^{-3}$ group $\left(1.5 \pm 0.2 \% \mathrm{~d}^{-1}\right.$, mean $\left.\pm \mathrm{SD}\right)$ was the highest, while the DFI of the $100 \mathrm{~kg} \mathrm{~m}^{-3}$ group was the lowest $\left(1.3 \pm 0.2 \% \mathrm{~d}^{-1}\right.$, mean $\left.\pm \mathrm{SD}\right)$. The DFI was the same $1.4 \pm 0.2 \% \mathrm{~d}^{-1}$, mean \pm SD for the other treatments $(10,40$ and $70 \mathrm{~kg} \mathrm{~m}^{-3}$ ).

Significant differences were observed (Table 3, Fig. 1), between the 20 and 40 which had the highest average SGR $\left(0.50 \% \mathrm{~d}^{-1}\right)$ compared to the 10 and $70 \mathrm{~kg} \mathrm{~m}^{-3}$ groups $(0.48$ and $\left.0.47 \% \mathrm{~d}^{-1}\right)$ and the $100 \mathrm{~kg} \mathrm{~m}^{-3}$ group $\left(0.43 \% \mathrm{~d}^{-1}\right)$. 

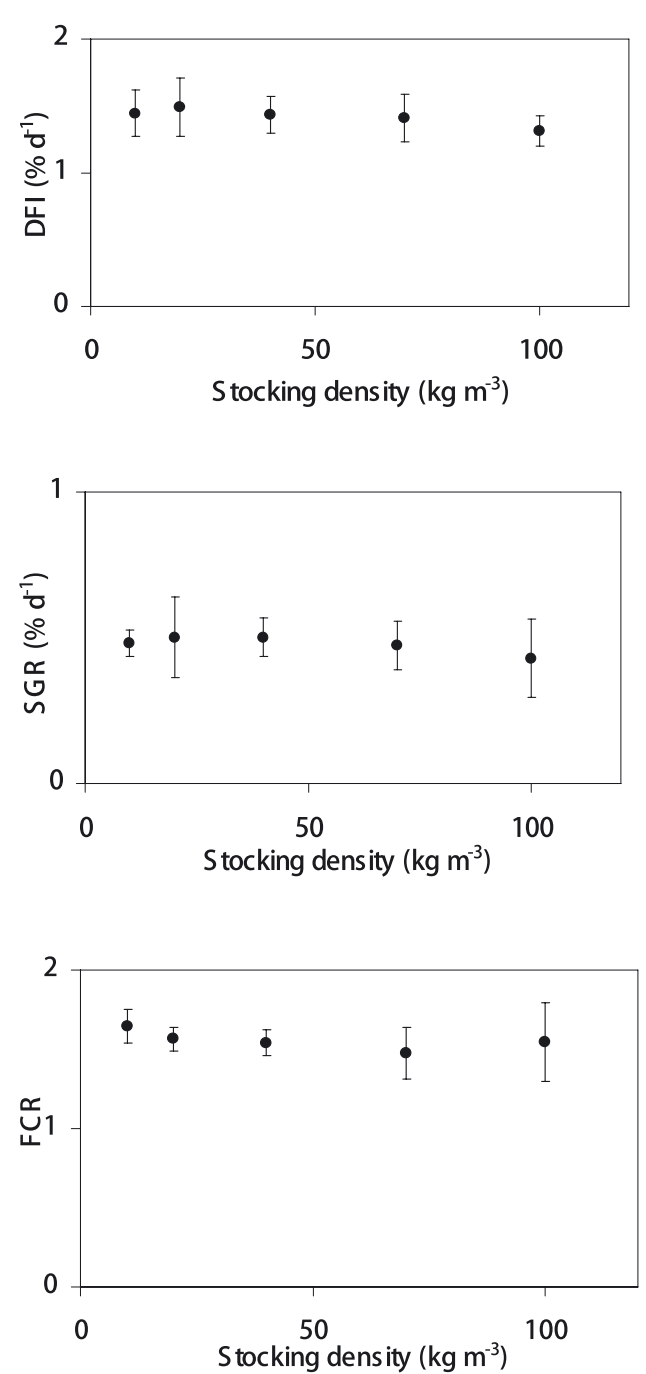

Fig. 1. Daily feed intake (DFI, $\% \mathrm{~d}^{-1}$ ), specific growth rate (SGR, $\% \mathrm{~d}^{-1}$ ) and feed conversion ratio (FCR) of sea bass reared at five density treatment $\left(10,20,40,70,100 \mathrm{~kg} \mathrm{~m}^{-3}\right)$ during the 84-day experiment. Statistical results are given, $N S$ as non significant difference $(p>0.05)$ between groups.

Finally, there were no significant differences $(p=0.312)$ between density groups concerning FCR (Table 3, Fig. 1). However, the retrospective power analysis showed weak statistical strength (23\%) behind this non-significant statement. The prospective power analysis showed that a significant difference would have been observed after a difference of 0.4 between the lowest FCR and the highest FCR means.

\subsubsection{Blood parameters}

Mean plasma concentration of $\mathrm{K}, \mathrm{pH}$ and haematocrit (Tables 4 and 5) did not show significant difference between density treatments. Statistical analysis showed a significant difference between mean plasma concentrations of $\mathrm{Na}$ and Glucose due to a tank effect relative to density (Table 4).
$\mathrm{TCO}_{2}, \mathrm{PCO}_{2}$ and $\mathrm{HCO}_{3}$ concentrations (Tables 4 and 5) increased significantly $(p<0.05)$ with density in accordance with the observed increase in swimming activity of the fish.

Mean serum protein concentration in fish reared at 10 and $40 \mathrm{~kg} \mathrm{~m}^{-3}$ was significantly higher than in fish reared at 70 and $100 \mathrm{~kg} \mathrm{~m}^{-3}$ (Fig. 2). This trend was confirmed at the end of the experiment, but with no significant difference.

No significant change in plasma cortisol was observed at the end of the rearing density trial (Two way ANOVA: ns) in groups reared at 10,40 and $100 \mathrm{~kg} \mathrm{~m}^{-3}$. After 84 days, mean cortisol concentrations were very low (less than $15 \mathrm{ng} \mathrm{ml}^{-1}$ ) in all groups, regardless of rearing density (Fig. 3). Multicomparison tests did not reveal any significant difference between and within groups at initial and final sampling.

\subsection{Resistance to infectious - $\mathbf{2 1}$ day challenge}

The morbidity peak appeared from day 4 to day 8 in all the density treatments, except for the control group where no mortalities were noticed (data not shown). At day 20 postinoculation, the final mean morbidity, ranged from 71 to $80 \%$ and no significant difference was observed between treatments (i.e. initial densities) (Fig. 4). Moreover, the morbidity of fish from $100 \mathrm{~kg} \mathrm{~m}^{-3}$ group was the lowest, although differences with other density groups were not statistically significant. The nodavirus was detected by ELISA in the brains of affected fish. No other diseases or pathogens were noticed on the affected fish.

\section{Discussion}

At all densities $\left(10,20,40,70\right.$ and $\left.100 \mathrm{~kg} \mathrm{~m}^{-3}\right)$, the water quality parameters were maintained in the range of values recommended for sea bass in aquaculture systems (Person-Le Ruyet et al. 1997; Blancheton 2000; Lemarié et al. 2004; Colt 2006). This made it possible to evaluate the monospecific potential effects of density on sea bass by dissociating the specific effects of biomass increase and water quality degradation.

Cumulative mortality rates were lower than $2.2 \%$ and did not seem to be affected by density, except for the $100 \mathrm{~kg} \mathrm{~m}^{-3}$ group, where it was higher (12.6\%). This was due to a specific pathology event occurring during $\mathrm{P} 2$ in one of the duplicates (high density facilitates disease transmission among reared animals). Without this pathology event, the cumulative mortality rate of the $100 \mathrm{~kg} \mathrm{~m}^{-3}$ group would have been in the same order of magnitude as in the other groups (around 1.5-2\%). This is in accordance with the results found in the recirculating aquaculture system (RAS) by Sammouth et al. (2009), who showed no differential fish mortality in density groups between 10 and $100 \mathrm{~kg} \mathrm{~m}^{-3}$ (1\% of average cumulative mortality).

DFI remained in the same order of magnitude $\left(1.3-1.5 \% \mathrm{~d}^{-1}\right)$ for all density groups. However, the daily feed intake of the $100 \mathrm{~kg} \mathrm{~m}^{-3}$ group $(1.3 \pm 0.1 \%)$ was significantly lower, resulting in a lower SGR $\left(0.43 \% \mathrm{~d}^{-1}\right)$. This is in agreement with Sammouth et al. (2009), who found significantly lower DFI and SGR for sea bass reared in RAS at $100 \mathrm{~kg} \mathrm{~m}^{-3}$ compared to lower densities. 
Table 4. Density effect on blood parameters and tank effect nested within density after 84 day exposure to different fish densities $(*: p<0.05$; $* *: p<0.01)$.

\begin{tabular}{lcccccccc}
\hline & $\mathrm{Na}$ & $\mathrm{K}$ & $\mathrm{T} \mathrm{CO}_{2}$ & $\mathrm{pCO}_{2}$ & $\mathrm{HCO}_{3}$ & $\mathrm{pH}$ & Glucose & $\mathrm{Hct}$ \\
\hline$F_{\text {Tank }}$ & $3.73^{* *}$ & 1.66 & 1.39 & 0.85 & 1.95 & 1.58 & $2.56^{*}$ & 1.34 \\
$F_{\text {density }}$ & 1.60 & 0.07 & $28.69^{* *}$ & $20.68^{* *}$ & $21.18^{* *}$ & 4.34 & 0.0 .5 & 0.34 \\
\hline
\end{tabular}

Table 5. Blood parameters after 84 day exposure to different fish densities; different letters following the means \pm SD in the same line indicate significant statistical differences $(p<0.05)$ between the density groups.

\begin{tabular}{lccc}
\hline & \multicolumn{3}{c}{ Density treatment $\left(\mathrm{kg} \mathrm{m}^{-3}\right)$} \\
\cline { 2 - 3 } & 10 & 40 & 100 \\
\hline $\mathrm{Na}\left(\mathrm{mmol} \mathrm{L}^{-1}\right)$ & $166.0 \pm 8.2$ & $159.4 \pm 8.5$ & $159.0 \pm 9.0$ \\
$\mathrm{~K}\left(\mathrm{mmol} \mathrm{L}^{-1}\right)$ & $6.0 \pm 0.9$ & $5.9 \pm 0.6$ & $5.8 \pm 0.7$ \\
$\mathrm{~T} \mathrm{CO}_{2}\left(\mathrm{mmol} \mathrm{L}^{-1}\right)$ & $8.0 \pm 0.9 \mathrm{a}$ & $10.8 \pm 1.0 \mathrm{~b}$ & $12.4 \pm 1.6 \mathrm{c}$ \\
$\mathrm{pCO}_{2}(\mathrm{~mm} \mathrm{Hg})$ & $21.1 \pm 2.9 \mathrm{a}$ & $25.5 \pm 2.8 \mathrm{~b}$ & $26.6 \pm 3.8 \mathrm{~b}$ \\
$\mathrm{HCO}_{3}\left(\mathrm{mmol} \mathrm{L}^{-1}\right)$ & $7.3 \pm 0.8 \mathrm{a}$ & $10.2 \pm 0.9 \mathrm{~b}$ & $11.5 \pm 1.5 \mathrm{c}$ \\
$\mathrm{pH}$ & $7.1 \pm 0.1$ & $7.2 \pm 0.1$ & $7.2 \pm 0.1$ \\
Glucose $\left(\mathrm{mg} \mathrm{L}^{-1}\right)$ & $101.9 \pm 21.4$ & $105.9 \pm 31.5$ & $103.0 \pm 33.8$ \\
Haematocrit $(\% \mathrm{pcv})$ & $24.4 \pm 2.4$ & $24.0 \pm 3.9$ & $24.8 \pm 3.8$ \\
\hline
\end{tabular}

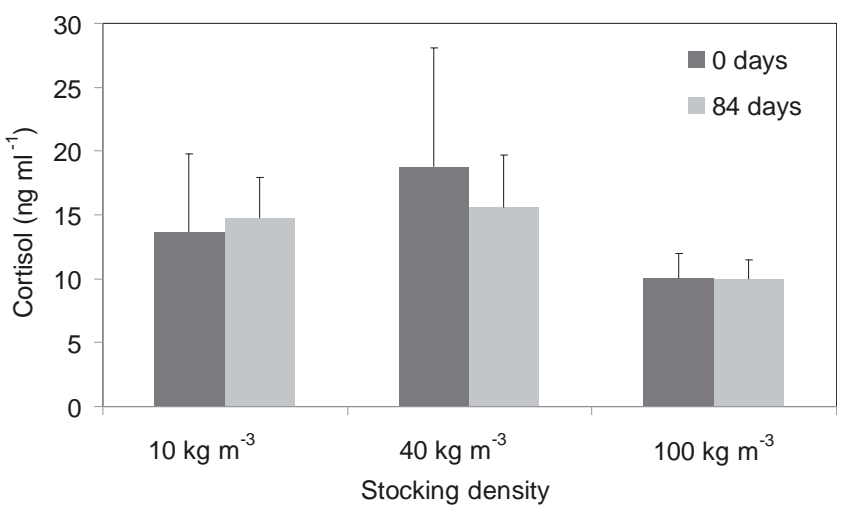

Fig. 2. Cortisol blood concentration (mean \pm SEM) of sea bass at the beginning and the end of the 84 day flow through experiment on fish held at two extreme densities $\left(10\right.$ and $\left.100 \mathrm{~kg} \mathrm{~m}^{-3}\right)$ and an intermediate density $\left(40 \mathrm{~kg} \mathrm{~m}^{-3}\right)$, according to Sammouth et al. (2009).

Both experiments, in FTS and RAS, showed that FCR remained unchanged whatever the density, suggesting no alteration of the feed assimilation capacity and/or changes in feeding behaviour (negative interaction during feeding at different densities). Power analysis showed a weak statistical strength behind this non-significant statement. However, FCR calculated values are close to the FCR observed with fish of the same weight in regular production systems with similar rearing conditions. As food access was not limiting during the experiment (ad libitum feeding and 2 automatic feeders per tank for the 70 and $100 \mathrm{~kg} \mathrm{~m}^{-3}$ groups to avoid fish competition), the lower DFI observed for the $100 \mathrm{~kg} \mathrm{~m}^{-3}$ group cannot easily be explained by feeding hierarchy developing and resulting in a physical obstruction as suggested by several authors (Wallace et al. 1988; Baker and Aylers 1990; Pickering 1992; Alanärä and Brännäs 1996; Ellis et al. 2002). As water quality and food access were not limiting, there were probably

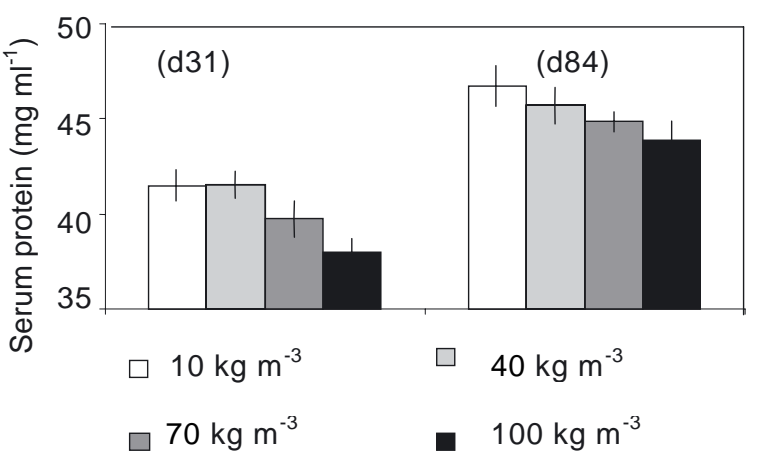

Fig. 3. Serum protein concentrations (mean \pm standard deviation) of sea bass reared at four densities $\left(\mathrm{kg} \mathrm{m}^{-3}\right)$ at day 31 and day 84 .

behavioural modifications occurring at $100 \mathrm{~kg} \mathrm{~m}^{-3}$ that led to fish performance reduction. Person-Le Ruyet et al. (2008) found similar results on rainbow trout reared in high quality water $\left(12 \mathrm{mg} \mathrm{O}_{2} \mathrm{~L}^{-1}\right.$ and $0.3 \mathrm{mg}$ TAN L $\left.{ }^{-1}\right)$ with no density effect on growth up to $74 \mathrm{~kg} \mathrm{~m}^{-3}$ and a growth decrease observed between 74 and $120 \mathrm{~kg} \mathrm{~m}^{-3}$.

No significant change in serum cortisol levels was observed in experimental groups reared at different densities, up to $100 \mathrm{~kg} \mathrm{~m}^{-3}$, confirming results from previous experiments in sea bass (Di Marco et al. 2003; Marino et al. 2004; Di Marco et al. 2008; Sammouth et al. 2009). Plasma cortisol concentration is lower than baseline values reported in the literature for this species (Marino et al. 2001; Di Marco et al. 2008). After 84 days, mean cortisol concentration in sea bass reared in FTS was found two times lower than cortisol levels measured in sea bass reared at the same experimental densities in RAS facilities (Sammouth et al. 2009). Few studies reported effects of rearing density on sea bass stress response. Terova et al. (2005) measured high plasma cortisol levels in juveniles reared for 3 months at 80 and $100 \mathrm{~kg} \mathrm{~m}^{-3}\left(124 \mathrm{ng} \mathrm{ml}^{-1}\right.$ and $280 \mathrm{ng} \mathrm{ml}^{-1}$ respectively) compared to cortisol levels at 


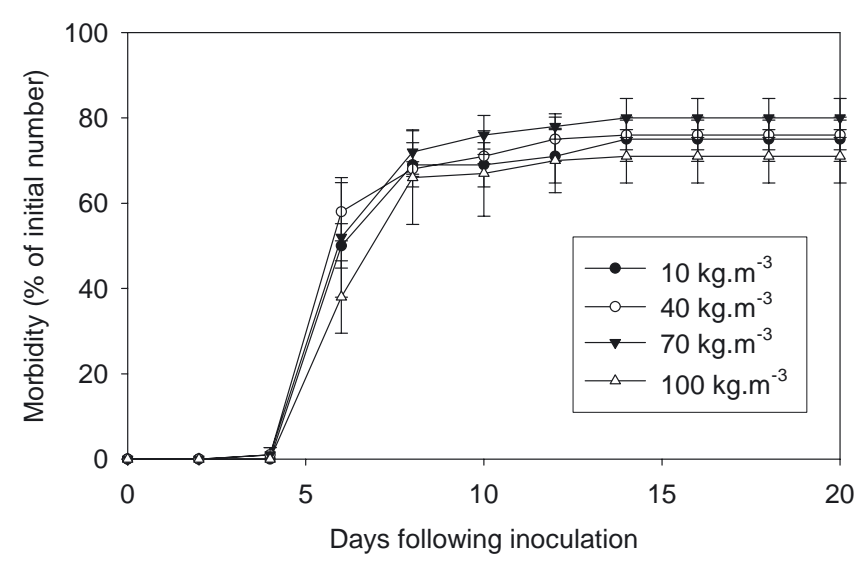

Fig. 4. Cumulative morbidity (mortality and fish showing nervous symptoms) following nodavirus challenge using fish from 4 different densities $\left(10,40,70\right.$ and $\left.100 \mathrm{~kg} \mathrm{~m}^{3}\right)$, expressed in $\%$.

$10 \mathrm{~kg} \mathrm{~m}^{-3}$ (60 $\left.\mathrm{ng} \mathrm{ml}^{-1}\right)$. However, this experiment was performed in $200 \mathrm{~L}$ fiberglass tanks and the increased plasma cortisol level may be due to the confinement of sea bass in a restricted space. Additionally, some studies suggested that high rearing densities are not a chronic physiological stress factor in sea bass and the reduction of fish growth and performance was not due to a high rearing density (Procarione et al. 1999).

As obtained under RAS conditions (Sammouth et al. 2009), no significant differences between density treatments were observed on the $\mathrm{K}, \mathrm{pH}$ and haematocrit blood parameters. These results are comparable to those of Person-Le Ruyet et al. (2008) who reported no sign of acute stress (i.e. physiological change in cortisol and glycemia) in trout reared at 25,74 and $120 \mathrm{~kg} \mathrm{~m}^{-3}$. She demonstrated that fish were more affected by water quality degradation than by rearing density.

Blood $\mathrm{CO}_{2}$ concentrations increased significantly with density as the effects of fish metabolism and respiratory activity. For the 40 and $100 \mathrm{~kg} \mathrm{~m}^{-3}$ groups, water $\mathrm{CO}_{2}$ concentrations were twice as high as for the $10 \mathrm{~kg} \mathrm{~m}^{-3}$ group, but remained under the value acceptable for fish aquaculture. Foss et al. (2006) observed similar tends on juvenile cod (Gadus morhua) exposed to gradual water quality levels, with $\mathrm{CO}_{2}, \mathrm{TCO}_{2}$ and $\mathrm{HCO}_{3}^{-}$blood concentrations increased with degree of water reuse. In our experiment, swimming levels, expressed as distance swum per time unit, significantly decreased with increasing density (Faucher et al. 2007), but fish were visually more restless at $100 \mathrm{~kg} \mathrm{~m}^{-3}$. This difference in fish behaviour could explain the slight increase in $\mathrm{CO}_{2}$ levels at $100 \mathrm{~kg} \mathrm{~m}^{-3}$. However, $\mathrm{CO}_{2}$ blood concentrations of the 3 density groups (varying from 8.0 to $12.4 \mathrm{mmol} \mathrm{L}^{-1}$ ) after the 84 day experiment were in the same range as values found by Person-Le Ruyet et al. (2008) for densities varying from 25 to $120 \mathrm{~kg} \mathrm{~m}^{-3}$ (plasma total $\mathrm{CO}_{2}$ concentrations of 7.4-12.3 $\mathrm{mmol} \mathrm{L}^{-1}$ ) after an 84 day experiment. Under the conditions of our study, as well as under RAS conditions (Sammouth et al. 2009), no correlation was established between blood $\mathrm{CO}_{2}$ concentrations and rearing density.

Proteinemia were significantly lower in fish reared at 70 and $100 \mathrm{~kg} \mathrm{~m}^{-3}$ compared to 40 and $10 \mathrm{~kg} \mathrm{~m}^{-3}$. This tendency was confirmed at the end of the experiment, but with no significant difference. Sutton et al. (2000) found a decrease in proteinemia correlated with crowding but the relation between proteinemia and rearing density is still not well documented. Complementary analysis by proteomic approach showed some variations in serum protein panel between fish reared at $10 \mathrm{~kg} \mathrm{~m}^{-3}$ and $100 \mathrm{~kg} \mathrm{~m}^{-3}$ (work in progress).

As under RAS conditions (Sammouth et al. 2009), no significant difference between density treatments were observed on fish nodavirus resistance. The rearing differences (i.e density level) were probably not acute enough for inducing measurable fish health differences. The same results were obtained with sea bass larvae and juveniles (15-20 g) submitted to tank scrubbing 3 times per day (5 min duration) during 3 months (Varsamos et al. 2006). However, same authors showed significant differences on serum IgM and plasma cortisol concentrations, weight and nodavirus resistance on fish submitted to repeated daily $5{ }^{\circ} \mathrm{C}$ thermal variations (from 17 to $23^{\circ} \mathrm{C}$ one day and vice-versa on alternate days) (Varsamos et al. 2006). This could suggest that a constant density of around $100 \mathrm{~kg} \mathrm{~m}^{-3}$ is less stressful for the fish than a daily temperature variation of $5{ }^{\circ} \mathrm{C}$. This could be potentially explained by high fish adaptability to constant density.

\section{Conclusion}

Biological performances (DFI, SGR) were decreased at $100 \mathrm{~kg} \mathrm{~m}^{-3}$, but no significant differences were noticed on stress response (cortisol) and disease resistance in sea bass reared in a flow through system at densities between $10-100 \mathrm{~kg} \mathrm{~m}^{-3}$. These results confirmed that a high density is not a chronic stress factor for sea bass when feed access is non limiting and water renewal rate per $\mathrm{kg}$ of fish biomass enables maintenance of the water quality parameters (mainly $\mathrm{O}_{2}$, $\mathrm{CO}_{2}$, TAN) within the range of recommended levels for such species. Decrease in growth performances at $100 \mathrm{~kg} \mathrm{~m}^{-3}$ in both RAS and FTS suggest that maximal density for sea bass should be comprised between 70 and $100 \mathrm{~kg} \mathrm{~m}^{-3}$, whatever the rearing system.

Acknowledgements. This work was part of the WEALTH project (2004-2007), aimed at defining pragmatic indicators to measure fish welfare status in fish farms. This project was made possible thanks to financial support from the European Union and the collaboration of private aquaculture companies and research partners. The experiments were conducted at the IFREMER station, Palavas. The authors are thankful to Ms. Aurélie Charrier for the water parameter control and analysis, Mr. Benoit Rollin for the logistics and all the students helping during the 3 years of the project. The authors would also like to thank Laure Grima-Morsiani and Marc Vandeputte (INRA) for their help on the statistical analyses.

\section{References}

Alanärä A., Brännäs E., 1996, Dominance in demand-feeding behaviour in Arctic charr and rainbow trout: the effect of stocking density. J. Fish Biol. 48, 242-254.

Ashley, P.J., 2007, Fish welfare: Current issues in aquaculture. Appl. Anim. Behav. Sci. 104, 199-235. 
Baker R.F., Ayles G.B., 1990, The effects of carrying density and loading level on the growth of Arctic charr (Salvelinus alpinus L.) and rainbow trout (Oncorhynchus mykiss). World Aquac. 21, $56-62$.

Benschneider K., Robinson R.J., 1952, A new spectrophotometric determination of nitrite in seawater. J. Mar. Res. 11, 87-96.

Blancheton J.P., 2000, Developments in recirculating systems for Mediterranean fish species. Aquac. Eng. 22, 17-31.

Björnsson B., Ólafsdóttir S.R., 2006, Effects of water quality and stocking density on growth performance of juvenile cod (Gadus morhua L.). ICES J. Mar. Sci. 63, 326-334.

Breuil G., Romestand B., 1999, A rapid ELISA method for detecting specific antibody level against nodavirus in the serum of the sea bass, Dicentrarchus labrax (L.): application in the screening of spawners in sea bass hatchery. J. Fish Dis. 22, 45-52.

Breuil G., Mouchel O., Fauvel C., Pépin J.F., 2001, Sea bass Dicentrarchus labrax nervous necrosis virus iolates with distinct pathogenicity to sea bass larvae. Dis. Aquat. Org. 45, 25-31.

Breuil G., Pépin J.F., Boscher S., Thiéry R., 2002, Experimental vertical transmission of nodavirus from broodfish to eggs and larvae of the sea bass Dicentrarchus labrax. J. Fish Dis. 25, 697-702.

Colt J., 2006, Water quality requirements for reuse systems. Aquac. Eng. 34, 143-156.

Conte F.S., 2004, Stress and the welfare of cultured fish. Appl. Anim. Behav. Sci. 86, 205-223.

Di Marco P., Priori A., Finora M.G., Massari A., Mandich A., Marino G., 2008, Physiological responses of European sea bass Dicentrarchus labrax to different stocking densities and acute stress challenge. Aquaculture 275, 319-328.

Dosdat A., Person-Le Ruyet J., Covès D., Dutto G., Gasset E., Le Roux A., Lemarié G., 2003, Effect of chronic exposure to ammonia on growth, food utilisation and metabolism of the European sea bass (Dicentrarchus labrax). Aquat. Living Resour. $16,509-520$.

Ellis T., North B., Scott A.P., Bromage N.R., Porter M., Gadd D., 2002, The relationships between stocking density and welfare in farmed rainbow trout. J. Fish Bio., 61, 3, 493-531.

Faucher K., Millot S., Blancheton J.P., Lemarié G., Dutto G., Bégout M.L., 2007, Effect of stocking density on cultured fish swimming behaviour: first results on sea bass using acoustic telemetry in flow through tanks., 7th Conference on Fish Telemetry, Silkeborg, Denmark.

Foss A., Kristensen T., Åtland A., Hustveit H., Hovland H., Øfsti A., Imsland A. K., 2006, Effects of water reuse and stocking density on water quality, blood physiology and growth rate of juvenile cod (Gadus morhua). Aquaculture 256, 255-263.

Jørgensen E.H., Christiansen J.S., Jobling M., 1993, Effects of stocking density on food intake, growth performance and oxygen consumption in Arctic charr (Salvelinus alpinus). Aquaculture 110, 191-204.

Lemarié G., Dosdat A., Covès D., Dutto G., Gasset E., Person-Le Ruyet J., 2004, Effect of chronic ammonia exposure on growth of European seabass (Dicentrarchus labrax) juveniles. Aquaculture 229, 479-491.
Marino G., Di Marco P., Mandich A., Priori A., Finoia M.G., Caudatella S., 2001, Change in serum cortisol, metabolites, osmotic pressure and electrolytes in response to different blood sampling procedures in culture sea bass (Dicentrarchus labrax L.). J. Appl. Ichthyol. 117, 115-120.

Meade J.W., 1989, Aquaculture Management. Van Nostrand Reinhold. New York, NY.

Noble A.C., Summerfelt S.T., 1996, Diseases encountered in rainbow trout cultured in recirculating systems. Ann. Rev. Fish Dis. 6, 6592.

North B.P., Turnbull J.F., Ellis T., Porter M.J., Migaud H., Bron J., Bromage N.R., 2006, The impact of stocking density on the welfare of rainbow trout (Oncorhynchus mykiss). Aquaculture 255, $1-4,466-479$.

Papoutsoglou S.E., Paraskeva-Papoutsoglou E., Alexis M.N., 1987, Effect of density on growth rate and production of rainbow trout (Salmo gairdneri Rich.) over a full rearing period. Aquaculture 66, 9-17.

Papoutsoglou S.E., Voutsinos G.A., Panetsos F., 1990, The effect of photoperiod and density on growth rate of Oreochromis aureus (Steindachner) reared in a closed water system. Anim. Sci. Rev. $11,73-87$.

Person-Le Ruyet J., Galland R., Roux A., Chartois H., 1997, Chronic ammonia toxicity to juvenile turbot (Scophthalmus maximus). Aquaculture 154, 155-171.

Person-Le Ruyet J., Pichavant K., Vacher C., Le Bayon N., Sévère A., Bœuf G., 2002, Effects of oxygen supersaturation on growth and metabolism in juvenile turbot (Scophthalmus maximus). Aquaculture 205, 373-383.

Person-Le Ruyet J., Mahé K., Le Bayon N., Le Delliou H., 2004, Effects of temperature on growth and metabolism in a Mediterranean population of European sea bass, Dicentrarchus labrax. Aquaculture, 237, 1-4, 269-280.

Person-Le-Ruyet J., Labbé L., Le Bayon N., Sévère A., Le Roux A., Le Delliou H., Quéméner L., 2008, Combined effects of water quality and stocking density on welfare and growth of rainbow trout (Oncorhynchus mykiss). Aquat. Living Resour. 21, 185-195.

Pichavant K., Person-Le Ruyet J., Le Bayon N., Sévère A., Le Roux A., Bœuf G., 2001, Comparative effects of long-term hypoxia on growth, feeding and oxygen consumption in juvenile turbot and European sea bass. J. Fish Biol. 59, 875-883.

Pickering A.D., 1992, Rainbow trout husbandry: management of the stress response. Aquaculture 100, 125-139.

Pickering A.D., Pottinger T.G., Carragher J.F., 1989, Differences in the sensitivity of brown trout, Salmo trutta L., and Rainbow trout, Salmo gairdneri Richardson, to physiological doses of cortisol. J. Fish Biol. 34, 5, 757-763.

Procarione L.S., Barry T.P., Malison J.A., 1999, Effect of high rearing density and loading rates on the growth and stress response of juvenile rainbow trout. N. Am. J. Aquac. 61, 91-96.

Roncarati A., Melotti P., Dees A., Mordenti O., Angellotti L., 2006, Welfare status of cultured seabass (Dicentrarchus labrax L.) and seabream (Sparus aurata L.) assessed by blood parameters and tissue characteristics. J. Appl. Ichthyol. 22, 225-234. 
Roque d'Orbcastel E., Person-Le-Ruyet J., Le Bayon N., Blancheton J.P., 2009, Comparative growth and welfare in rainbow trout reared in re-circulating and flow through rearing systems. Aquac. Eng. 40, 79-86.

Sammouth S., Roque d'orbcastel E., Gasset E., Lemarié G., Breuil G., Marino G., Fivelstad S., Coeurdacier J.L., Blancheton J.P., 2009, Effect of stocking density on seabass (Dicentrarchus labrax) performance in a recirculating system. Aquac. Eng. 40, 72-78.

Solorzano L., 1969, Determination of ammonia in natural waters by the phenol-hypochlorite method. Limnol. Oceanol. 14, 799-801.

Sutton R.J., Caldwell A.C., Blaze V.S., 2000, Observations of health indices used to monitor a tailwater trout fishery. N. Am. J. Fish. Manage., 20, 267-275.

Terova G., Gornati R., Rimoldi S., Bernardini G., Saroglia M., 2005, Quantification of a glucocorticoid receptor in sea bass (Dicentrarchus labrax L.) reared at high stocking density, Gene 357, 144-151.
Turnbull J., Bell A., Adams C., Bron J., Huntingford F., 2005, Stocking density and welfare of cage farmed Atlantic salmon: application of a multivariate analysis. Aquaculture 243, 121-132.

Varsamos S., Flik G., Pépin J.F., Wendelaar Bonga S.E., Breuil G., 2006, Husbandry stress during early life stages affects the stress response and health status of juvenile sea bass, Dicentrarchus labrax. Fish Shellfish Immunol. 20, 83-96.

Wallace J.C., Kolbeinshavn A.G., Reinsnes T.G., 1988, The effects of stocking density on early growth in Artic charr, Salvelinus alpinus (L.). Aquaculture 73, 101-110.

Wood E.D., Armstrong F.A.J., Richards F.A., 1967, Determination of nitrate in sea water by cadmium cooper reduction to nitrite. J. Mar. Biol. 47, 23-31

Zoccarato I., Benatti G., Bianchini M.L., Boccignone M., Conti A., Napolitano R., Palmegiano G.B., 1994, Differences in performance, flesh composition and water output quality in relation to density and feeding level in rainbow trout, Oncorhynchus mykiss (Walbaum) farming. Aquac. Fish. Manage. 25, 239-647. 